\author{
ŁUKASZ JAN KORPOROWICZ OPs \\ Wydział Prawa i Administracji \\ Uniwersytetu Łódzkiego
}

\title{
BONA FIDES PRAESCRIPTIO. KANON 41 (QUONIAM OMNE) IV SOBORU LATERAŃSKIEGO (1215) A PRAWO RZYMSKIE
}

Treść: Wprowadzenie. - 1. Wiara (fides) jako przesłanka zasiedzenia w prawie rzymskim. - 2. Fides a zasiedzenie według prawa kanonicznego. - 3. Kan. 41 Quoniam omne w perspektywie wcześniejszego prawodawstwa papieskiego. - Zakończenie.

\section{Wprowadzenie}

Zebrani na IV Soborze laterańskim Ojcowie soborowi, pośród licznych rozstrzygnięć doktrynalnych podjęli również szereg decyzji dotyczących zagadnień procesowych. Wśród nich szczególne miejsce zajmują trzy kanony, które choć odnosiły się również do zagadnień formalnoprawnych, to łączył je jednak przede wszystkim problem oceny szeroko rozumianego posiadania i kwestii jemu pokrewnych. Pierwsze ze wspomnianych rozstrzygnięć dotyczyło zagadnienia nabycia rzeczy od nieuprawnionego. Drugi kanon dotyczył posiadania rzeczy spornej w razie niestawiennictwa strony procesowej. Wreszcie trzecim ze wspomnianych postanowień soborowych był kanon 41 Quoniam omne1. Dotyczył on wymogu dobrej wiary niezbędnej do nabycia własności rzeczy w drodze zasiedzenia. Konstrukcja kanonu

\footnotetext{
${ }^{1}$ Pozostałe kanony stały się przedmiotem dwóch opracowań naukowych: Ł.J. Korporowicz, Rzymskie inspiracje kanonu 39 (Saepe contingit) IV Soboru Laterańskiego (1215), Łódzkie Studia Teologiczne 25(2016), nr 2, s. 91-102 oraz TENżE,
} 
oraz użyta w jego treści frazeologia wyraźnie wskazują na powiązania $\mathrm{z}$ tradycją prawa rzymskiego.

\section{Wiara ( fides) jako przesłanka zasiedzenia w prawie rzymskim}

Interpretowanie czynności prawnych przez pryzmat wiary, a dokładnie dobrej wiary, znane było Rzymianom już na wczesnym etapie rozwoju ich porządku prawnego ${ }^{2}$. Z kolei w kontekście instytucji zasiedzenia, bona fides zaczęła być przedmiotem zainteresowania prawników rzymskich w okresie prawa klasycznego. Dotyczyło to zarówno zasiedzenia w ścisłym tego słowa znaczeniu (usucapio) jak i w odniesieniu do zarzutu długiego okresu posiadania (longi temporis praescriptio), któremu na pewnym etapie rozwoju zaczęto przyznawać również skutki charakterystyczne dla zasiedzenia sensu stricto ${ }^{3}$. W prawie justyniańskim potwierdzono znaczenie dobrej wiary jako jednej z przesłanek zasiedzenia, co znalazło następnie swój wyraz w mnemotechnicznej wyliczance: res hablilis, titulus, fides, possessio, tempus ${ }^{4}$. Warto zwrócić uwagę jednak na fakt, iż przywołany heksametr wymienia jako przesłankę zasiedzenia fides, nie zaś bona fides. Związane było to $\mathrm{z}$ faktem, iż prawo rzymskie wymagało aby posiadacz legitymował się dobrą wiarą jedynie w momencie nabycia

Kanon 40 (Contingit interdum) IV Soboru Laterańskiego (1215) a prawo rzymskie, Acta Universitatis Lodziensis. Folia Iuridica 80(2017), s. 47-54.

${ }^{2} \mathrm{Na}$ temat genezy pojęcia fides zob. ostatnio R. FIORI, Hierarchia społeczna i kategorie prawne. Fides $\mathrm{i}$ bona fides, w: Noctes Iurisprudentiae. Scritti in onore di Jan Zabłocki, red. P. Niczyporuk, A. Tarwacka, Białystok 2015, s. 67-83.

${ }^{3}$ Por. J. PATsCh, Die Longi temporis praescriptio im klassichen Römischen Recht, Leipzig 1906, s. 7-19; L. Lombard, Dalla «fides» alla «bona fides», Milano 1961, s. 209-222; W. RozWAdowski, Zasiedzenie nieruchomości w dobrej wierze w prawie cywilnym na tle prawa rzymskiego, w: W kręgu teoretycznych i praktycznych aspektów prawoznawstwa. Księga jubileuszowa profesora Bronisława Ziemianina, red. M. Zieliński, Szczecin 2005, s. 238-240.

${ }^{4}$ Tradycyjnie uważa się, iż przywołany heksametr pochodzi z okresu średniowiecza. Ostatnio, w przekonujący sposób, tezę tę zanegował jednak E.J.H. Schrage w artykule: res habilis, titulus, fides, possessio, tempus. A medieval mnemonic hexameter?, w: Liber Amicorum Guido Tsuno, red. F. Sturm, Ph. Thomas, J. Otto, H. Mori, Frankfurt am Main 2013, s. 341-355. 
rzeczy i wejścia na drogę zmierzającą do nabycia własności przez zasiedzenie. Późniejsza zła wiara (mala fides) była w większości przypadków akceptowana zgodnie z paremią mala fides superveniens non nocet. Wyjątek od zasady wprowadzony został konstytucją Justyniana z roku 528, którą cesarz wydał w celu przeprowadzenia reformy przedmiotowej instytucji ${ }^{5}$. Wprowadził on do obrotu prawnego nadzwyczajną jej formę, określaną mianem longissimi temporis praescriptio, w odniesieniu do której wydłużył wymagany prawem tempus, aż do trzydziestu, a w niektórych przypadkach nawet do czterdziestu lat. Później, opierając się na swoich dotychczasowych rozstrzygnięciach, Justynian ogłosił, iż możliwość nabycia dóbr należących do kościołów bądź klasztorów istniała tylko pod warunkiem zachowania dobrej wiary przez cały potrzebny do zasiedzenia czas ${ }^{6}$. Inna konstytucja $\mathrm{z}$ roku 535 rozszerzyła $\mathrm{z}$ kolei niezbędny czas do nabycia w drodze zasiedzenia rzeczy należących do Stolicy Świętej do lat stu ${ }^{7}$. Zawsze jednak, gdy przedmiotem zasiedzenia były rzeczy należące do Kościoła wskazywano, iż mala fides superveniens nocet.

\section{Fides a zasiedzenie według prawa kanonicznego}

Problem zasiedzenia już na stosunkowo wczesnym etapie Jego działalności prawodawczej zainteresował również Kościół ${ }^{8}$ Na Soborze chalcedońskim, w roku 451, postanowiono na przykład, iż parafie

\footnotetext{
${ }^{5}$ C. $7,39,8$.

${ }^{6}$ Nov. 131, 6. Trzeba zaznaczyć jednak, iż czas niezbędny do uzyskania własności w drodze zasiedzenia rzeczy był tą przesłanką, która w rozwoju prawa rzymskiego ulegała częstym zmianom. Inicjatorami takich zmian były zarówno władze państwowe (cesarskie), jak i kościelne. Jako przykład wskazać można, iż w roku 349 wydana została przez Konstancjusza II i Konstansa konstytucja, w które ustalony został termin annorum quadraginta praescriptio (C.Th. 4, 11, 2). Więcej na temat tych zmian zob. E. Levy, West Roman Vulgar Law. The Law of Property, Philadelphia 1951, s. 180-193. Por. również Ł.J. Kor Porowicz, Roman Tax Policy in Roman Britain, Revue Internationale des Droits de l'Antiquité 61(2014), s. 249-251.

${ }^{7}$ Nov. 9.

${ }^{8}$ Uwagi ogólne na temat roli prawa rzymskiego w epoce patrystycznej zob. J. De Churruca, Patristica y derecho Romano, Estudios de Deusto 32(1984), nr 2, s. $429-444$.
} 
wiejskie mogą nabyć własność nieruchomości wraz z upływem trzydziestu lat ciągłego posiadania sine violentia ${ }^{9}$. Użyte sformułowanie można uznać za odpowiednik terminu mala fides. Jeszcze wyraźniej paralela taka ujawnia się w sformułowaniu użytym przez uczestników IV Synodu w Toledo w roku 633. Ojcowie synodalni stwierdzili bowiem, iż okres trzydziestu lat powinien upłynąć sine aliqua interpellatione, czyli że we wskazanym okresie nikt nie powinien wystąpić z roszczeniami dotyczącymi uprawnień w stosunku do przedmiotu zasiedzenia. Gdyby jednak taka osoba pojawiła się, wówczas posiadacz rzeczy uznany byłby za posiadacza w złej wierze ${ }^{10}$. Problem zasiedzenia podejmowały również synody w państwie Merowingów. Piszący na ten temat S. Esders stwierdził nawet, iż problem ten był häufig Streitfragen auf den gallischen Konzilien ${ }^{11}$.

Ze względu na podejmowane zagadnienie interesująca wydaje się być również jedna z wypowiedzi św. Augustyna z Hippony. Doktor Kościoła, w liście napisanym w roku 414 do Macedoniusa, stwierdził, iż źle posiada ten, kto źle realizuje swoje uprawnienie (male autem possidet, qui male utitur $)^{12}$. Augustyn wyraził powyższą opinię w nawiązaniu do fragmentu pochodzącego z biblijnej Księgi Przysłów i w kontekście zagadnienia gromadzenia przez chrześcijan bogactw. Powołany cytat nie dotyczy wprawdzie problemu zasiedzenia jako takiego, jednak wyraziście $\mathrm{z}$ nim koresponduje ${ }^{13}$.

Inny doktor Kościoła - św. Izydor z Sewilli - odniósł się dwukrotnie do koncepcji zasiedzenia, rozumianego jako usucapio. Wpierw

\footnotetext{
${ }^{9}$ C. 16 q. 3 c. 1.

${ }^{10}$ C.16 q.3 c. 4 .

${ }^{11}$ S. EsDERs, Römische Rechtradition und merowingisches Königtum. Zum Rechtscharakter politischer Herrschaft in Burgund in 6. und 7. Jahrhundert, Göttingen 1997, s. 257.

${ }^{12}$ Ep. 153, 6, 26.

${ }^{13} \mathrm{Na}$ temat wykorzystania przez św. Augustyna siatki pojęciowej prawa rzymskiego zob. F. Lardone, Roman Law in the Works of St. Augustine, Georgetown Law Journal 21(1933), nr 4, s. 435-456 oraz J. KodRĘBSKI, Św. Augustyn wobec prawa rzymskiego, Zeszyty Naukowe UŁ. Nauki Humanistyczno-Społeczne, ser. I, 38(1965), s. 37-49.
} 
wskazał, iż stanowi ono jedną z tych instytucji prawa, która zarezerwowana była Kwirytom ${ }^{14}$. Nieco dalej przedstawił z kolei definicję zasiedzenia, jako nabycia własności poprzez nieprzerwane słuszne posiadanie (continuationem iustae possessionis) trwające przez okres dwóch bądź więcej lat ${ }^{15}$. Użycie terminu iusta possessio jest przykładem zastosowania techniczno-prawnego języka przez Izydora. Pojęcie to używane było bowiem uprzednio przez jurystów rzymskich na określenie posiadania, które nie zostało nabyte przy pomocy siły, podstępu, czy z tytułu prekarium (nec vi, nec clam, nec precario). Brak i tym razem bezpośredniego odwołania do pojęcia fides, jednak nie ulega wątpliwości, iż działania nec vi, nec clam, nec precario nie mogłyby zostać zakwalifikowane jako bona lecz raczej jako mala fides. Na marginesie zauważyć można, iż sformułowanie nec vi koresponduje z użytym przez Ojców soborowych w Chalcedonie terminem sine violentia.

Co prawda rozważania św. Izydora dotyczyły prawa rzymskiego, nie zaś kanonicznego, jednak pamiętać trzeba, iż dzieła biskupa Sewilli - a w szczególności jego traktat De legibus - stanowiły poważne źródło inspiracji dla kanonistyki. Rzymska koncepcja zasiedzenia, czy to rozumianego jako usucapio, czy też jako (longi temporis) praescriptio zakładała obowiązywanie reguły mala fides superveniens non nocet. Dla Kościoła musiał być to zatem istotny problem, skoro w ujęciu teologicznym trzeba było powiedzieć, że prawo dopuszczało skutki grzechu. Jak zauważył zaś R.H. Helmholz prezentując omawiane zagadnienie: "long continuation of a sin cannot make the act less sinful ${ }^{16 "}$.

Jeszcze przed nastaniem okresu klasycznego prawa kanonicznego, interesujące odwołania do problemu zasiedzenia odnaleźć można w korespondencji papieskiej. Eugeniusz II (824-827) w swoim liście skierowanym do arcybiskupa Bernarda z Vienne, poinformował hierarchę, iż udało się odnaleźć justyniańskie prawo dotyczące

\footnotetext{
${ }^{14}$ Etym. 5, 9, 1.

${ }^{15}$ Etym. 5, 25, 30.

${ }^{16}$ R.H. Helmholz, The Spirit of Classical Canon Law, Athens-London 1996, s. 176.
} 
trzydziesto i czterdziestoletniego terminu wymaganego dla nabycia własności w drodze zasiedzenia venerabilibus locis ${ }^{17}$. Nie ulega wątpliwości, iż odnalezionym prawem musiał być fragment jednej z nowel justyniańskich dotyczących przedmiotowego zagadnienia. Warto zwrócić ponadto uwagę, że znajdujące się w liście zapewnienie papieskie dotyczy korzystania przez Kościół z dorobku myśli prawa rzymskiego. Eugeniusz II stwierdził bowiem, iż quidquid post auctoritatem Romanam, in Justiniana etiam lege comperimus ${ }^{18}$. Odkrycie dokonane za pontyfikatu Eugeniusza II musiało sprawić, iż w archiwach papieskich podjęto dalsze poszukiwania. Pośrednio świadczy o tym datowany na maj 873 roku list autorstwa Jana VIII (872-882) skierowany do Ludwika II Niemieckiego, w którym zaświadcza on o stuletnim okresie zasiedzenia stwierdzając ponadto: sed et venerande Romane leges divinitus per ora piorum principum promulgate rerum eius prescriptionem nonnisi post centum annos admittunt ${ }^{19}$.

Początków kanonistycznego przewrotu w zakresie rozumienia pojęcia zasiedzenia, a w tym i pojęcia fides jako jednej z jego przesłanek, upatrywać należy w działalności Gracjana. Ojciec prawa kanonicznego zebrał w swojej kompilacji znaczną liczbę papieskich, soborowych i synodalnych rozstrzygnięć dotyczących omawianej instytucji. To w oparciu o to zestawienie możliwe było prowadzenie dalszych prac interpretacyjnych ${ }^{20}$. Odnosząc się do samego pojęcia fides, trzeba stwierdzić, iż prace prawników zwieńczone zostały wydaniem w roku 1180 przez papieża Aleksandra III (1151-1181) dekretału Vigilanti $^{21}$. Biskup Rzymu ogłosił, iż prawo Boże nie zezwala na to

\footnotetext{
${ }^{17}$ Mansi, t. XIV, kol. 414-415.

${ }^{18}$ Zob. również A. DęBıński, Kościół a prawo rzymskie, Lublin 2007, s. 82, przyp. 264.

${ }^{19}$ Fragmenta registri Iohannis VIII. Papae. Ind. VI-IX (A. 872-876), w: Monumenta Germaniae Historica. Epistolarum tomus VII. Karolini Aevi V, Berolini 1928, s. 280-281.

${ }^{20}$ Szczegółową analizę Decretum Gracjana z punktu widzenia instytucji zasiedzenia przedstawił R.H. Helmholz, dz. cyt., s. 178-185.

${ }^{21} \mathrm{X}$. 2.26.5 Vigilanti studio cavendum est, quum summa dimensio divini iudicii ab initio censuerit propria dimittere, aliena non appetere, ne malae fidei possessors
} 
aby ktokolwiek posiadał w złej wierze przez długi czas dobra ziemskie należące do kogoś innego bądź rzeczy należące do Kościoła. Jednocześnie papież odrzucił wszelkie przeciwne zwyczaje. W dekretale wskazano ponadto, iż nawet osoba, która przez trzydzieści bądź czterdzieści lat posiadała omyłkowo rzeczy należące do kogoś innego i dowiedziała się po ich upływie o braku swojego uprawnienia w stosunku do nich, nie może zostać uznana za słusznego posiadacza. Podsumowując papież zaznaczył, iż nabycie posiadania rzeczy w złej wierze nigdy nie jest możliwe, niezależnie od tego czy dana rzecz pozostawała znana czy ukryta (in rebus cognitis quam in rebus latentibus placuit non habere vigorem).

Trudno orzec na ile dekretał Vigilanti okazał się skuteczny, jednak pewne jest, iż zawarte w nim założenia doktrynalne wymagały powtórzenia oraz uszczegółowienia. Problemu dobrej wiary dotyczyły bezpośrednio przynajmniej dwa inne dekretały - wydane przez Innocentego III: Si diligenti meditatione ${ }^{22} \mathrm{z}$ dnia 6 maja 1206 roku $^{23}$ oraz Veniens ad praesentiam ${ }^{24} \mathrm{z}$ dnia 3 marca 1212 roku. W pierwszym wskazano, iż nie mogą zasiedzieć rzeczy te osoby, które władają w cudzym imieniu oraz które pozbawione są dobrej wiary oraz słusznego tytułu (iustus titulus). W drugim natomiast zwrócono uwagę na fakt, iż w sytuacji, w której zasiedzenie „nie zostało zakończone” (praescriptio non erat completa), a podmiot pozostający na drodze do zasiedzenia jest w złej wierze, nie może on osiągnąć pożądanego

simus in praediis alienis, atque rebus [maxime] ecclesiasticis, quoniam nulla antiqua dierum possession divino iure iuvat aliequem malae fidei possessorem, nisi resipuerit, postquam se noverit aliena possidere, quum iure etiam bonae fidei possessor dici non possit. Ephesinus enim legislator Origenis patruus solum propter vitandam miserorum segnitiem et longi temporis errorem et confusionem primus tricennali vel quadragenali praescriptioni vigorem legis imposuit. Nobis autem tam in rebus cognitis quam in rebus latentibus placuit non habere vigorem.

${ }^{22}$ X. 2.26.17.

${ }^{23}$ Daty wydania dekretałów podane za A. Potтhast, Regesta Ponficium Romanorum. Inde ab A. post Christum natum MCXCVIII ad A. MCCCIV, vol. 1, Berolini 1874.

${ }^{24}$ X. 2.26.19. 
skutku prawnego. Prócz prawodawcy kościelnego, problem dobrej wiary interesował także działających na przełomie XII i XIII wieku dekretystów i dekretalistów. Jak wskazał U. Navarrete sam tylko dekret Vigilanti komentowali Simonis Bisignano, Huguccio, Ricardus Anglicus, Alanus Anglicus czy Bernardus Papiensis ${ }^{25}$.

\section{Kan. 41 Quoniam omne w perspektywie wcześniejszego prawodawstwa papieskiego}

Zasada wyrażona przez Aleksandra III w roku 1180, a następnie żywo komentowana przez kanonistów, powtórzona została w kanonie 41 Quoniam omne, IV Soboru laterańskiego. Soborowe rozstrzygniecie brzmi:

Quoniam omne quod non est ex fide, peccatum est, synodali iudicio definimus, ut nulla valeat absque bona fide praescriptio tam canonica quam civilis, cum sit generaliter omni constitutioni atque consuetudini derogandum, quae absque mortali non potest observari peccato. Unde oportet ut, qui praescribit, in nulla temporis parte rei habeat conscientiam alienae ${ }^{26}$.

Interpretacja przywołanego dekretu soborowego nastręcza pewnych trudności. Na wstępie Ojcowie soborowi przywołali fragment pochodzący z Listu św. Pawła do Rzymian ${ }^{27}$. Fakt ten wydaje się być znamienny, gdyż lokuje on dalsze rozstrzygnięcie w perspektywie

\footnotetext{
${ }^{25}$ U. NAVARREte, La buena fe de las personas juridicas en orden a la prescripcion adquisitiva. Estudio historic-canonico, Roma 1959, s. 48-53.

${ }^{26}$ X. 2.26.20. Skoro „wszystko co nie jest z wiary, jest grzechem”, decyzją Soboru postanawiamy, że żaden przepis - zarówno kanoniczny, jak i cywilny - nie ma mocy bez dobrej wiary; każdą ustawę i każdy zwyczaj należy uchylić jeśli nie mogą być przestrzegane bez grzechu śmiertelnego. Przeto jest rzeczą konieczną, aby prawodawca nigdy nie miał wątpliwości, że rzecz jest słuszna (tłumaczenie za Dokumenty Soborów Powszechnych. Tekst grecki, łaciński, polski, t. 2, 869-1312, układ i oprac. A. Baron, H. Pietras, Kraków 2003, s. 279). Należy zwrócić uwagę, iż w przywołanym tłumaczeniu wkradł się błąd. Tłumacze oddali bowiem łaciński termin praescriptio jako przepis.

${ }^{27}$ Rzym. 14, 23.
} 
prawa Bożego, nie zaś kościelnego. Tym samym potwierdzona została myśl, którą wyartykułował uprzednio Aleksander III, pisząc w dekretale Vigilanti: quum summa dimensio divini iudicii ab initio censuerit propria dimittere. Dalej dopiero ogłoszono, iż żadna praescriptio, czy to z prawa kanonicznego czy z prawa cywilnego, nie wywołuje skutków prawnych jeśli nie jest sprawowana w dobrej wierze. Rozstrzygnięcie to jest bezpośrednim ustosunkowaniem się do sporów trwających w nauce prawa na temat charakteru zasiedzenia. W ten sposób Quoniam omne jest także interpretowane w literaturze przedmiotu $^{28}$.

Pytanie pojawia się wszakże w odniesieniu do sformułowania qui praescribit w ostatnim zdaniu dekretu soborowego. Teoretycznie bowiem stwierdzenie unde oportet ut, qui praescribit, in nulla temporis parte rei habeat conscientiam alienae wydaje się być tożsame z paralelnym fragmentem zawartym w dekretale z 1180 roku (postquam se noverit aliena possidere, quum iure etiam bonae fidei possessor dici non possit). Użyte jednak w Quoniam omne sformułowanie qui praescribit jest raczej odczytywane w znaczeniu „który uzyskuje wskutek przedawnienia”, nie zaś „który uzyskuje wskutek zasiedzenia”. W ten sposób czasownik praescribere rozumieją przykładowo A. Jougan i J. Sondel ${ }^{29}$. Należy stwierdzić jednak, iż proponowane tłumaczenie analizowanego czasownika nie wyklucza odnoszenia go do uzyskiwania skutku zasiedzenia. Wskazuje na to analiza wydań Corpus Iuris Canonici, a dokładnie tytułu De praescriptionibus Dekretałów Grzegorza IX. W tytule tym św. Rajmund z Penyafort OP zawarł dwadzieścia rozstrzygnięć odnoszących się do pojęcia praescriptio. Analizując summaria znajdujące się przed kolejnymi rozdziałami tytułu dostrzec

\footnotetext{
${ }^{28}$ Por. U. Navarrete, dz. cyt., s. 54-66; R.H. Helmholz, dz. cyt., s. 189.

${ }^{29}$ A. Jougan, Słownik kościelny łacińsko-polski, Miejsce Piastowe 1948, s. 476, s.v. Praescribo, scripsi, script; J. Sondel, Słownik łacińsko-polski dla prawników i historyków, Kraków 2006, s. 777, s.v. Praescribo-scripsi-scriptum. Zob. również T. Dy DYŃski, Słownik łacińsko-polski do źródeł prawa rzymskiego, Warszawa 1883, s. 529-530, s.v. Preaescribere. Zupełnie odrzucić należy natomiast tłumaczenie proponowane przez A. Barona i H. Pietrasa, którzy sformułowanie qui praescribit oddają jako „prawodawca”.
} 
można, iż czasownik praescribere użyty został w nich wielokrotnie, także tam, gdzie z pewnością praescriptio oznacza zasiedzenie ${ }^{30}$.

Ustalenie faktu, iż praescribere odnosi się do zasiedzenia nie zmienia jednak faktu, iż słowo to używane jest również w znaczeniu, jakie w swoich słownikach nadają mu wskazani uprzednio A. Jougan czy J. Sondel. Pomocne w dalszych rozważaniach będzie przyjrzenie się wewnętrznej strukturze tytułu De praescriptionibus. Na dwadzieścia powołanych źródeł składają się: pochodzący z kompilacji Dionizjusza Małego fragment akt jednego z synodów afrykańskich ${ }^{31}$, dwa rozstrzygnięcia prawne przypisywane Grzegorzowi Wielkiemu ${ }^{32}$, sześć dekretałów Aleksandra III (w tym Vigilanti) ${ }^{33}$, jeden dekretał Lucjusza III $^{34}$, dziewięć dekretałów Innocentego III $^{35}$ i soborowy kanon Quoniam omne. Ze względów merytorycznych zebrany materiał podzielić można na dwie grupy: pierwszą dotyczącą zasiedzenia rzeczy bądź jakiegoś miejsca (niekoniecznie chodzi tutaj o nieruchomość ale na przykład o diecezję), drugą zaś odnoszącą się do wygaśnięcia określonych uprawnień i nabycia ich przez inny podmiot (np. pobieranie dziesięciny czy przejęcie uprawnień biskupich), co należy w kontekście użytego tam słowa praescribere rozumieć jako ich przedawnienia. Gdy chodzi o pojawiające się w treści tytułu odniesienia do tempus szybko dostrzec można, iż kościelni prawodawcy recypowali w tym zakresie prawo rzymskie. W dokumentach pojawiają się zatem informacje o zasiedzeniu trwającym lat trzydzieści, czterdzieści oraz sto w odniesieniu do Stolicy Apostolskiej ${ }^{36}$. Warte odnotowania są

\footnotetext{
${ }^{30}$ Mowa tu o: X. 2.26.1; 2.26.3; 2.26.4-7; 2.26.9; 2.26.17.

${ }^{31}$ X. 2.26.1.

${ }^{32}$ X. 2.26.2-3.

${ }^{33}$ X. 2.26.4-9.

${ }^{34}$ X. 2.26.10.

${ }^{35}$ X. 2.26.11-19.

${ }^{36}$ X. 2.26.13-14. Na temat stuletniego okresu zasiedzenia w prawodawstwie Innocentego III zob. J. Petersohn, Kaiser, Papst und römisches Recht im Hochmittelalter. Friedrich Barbarossa und Innocenz III. beim Umgang mit dem Rechtsinstitut der langfristigen Verjährung, w: Mediaevalia Augiensia. Forschung zur Geschichte des Mittelalters, red. J. Petersohn, Stuttgart 2001, s. 337-341.
} 
również sformułowane w treści omawianych dokumentów zasady ogólne, np. czas zasiedzenia nie biegnie w odniesieniu do rzeczy, które zajęte zostały przemocą (in rebus invasis non currit praescriptio) ${ }^{37}$; posiadanie rzeczy prowadzące do zasiedzenia powinno być spokojne i słuszne (quiete et sincere) ${ }^{38}$; czas, w którym wakuje stolica biskupia nie jest doliczany do biegu terminu ${ }^{39}$.

Początkowo problem rozróżnienia zasiedzenia od przedawnienia nie jest łatwy. W pierwszych dziesięciu rozstrzygnięciach (do dekretału Ex transmissa Lucjusza III włącznie) wyraźnie uwypukla się znaczenie praescriptio rozumianej jako zasiedzenie, nawet tam gdzie kazus dotyczy sprawowania jakiegoś urzędu. Dopiero pontyfikat Innocentego III przyniósł bardziej stanowcze rozróżnienie omawianego pojęcia np. zakaz przedawnienia - objęcia przez osobę do tego niepowołaną - zadań powierzonych legatom i nuncjuszom Stolicy Apostolskiej ${ }^{40}$ czy zakaz przejmowania przez podwładnych (subditus) zadań powierzonych prałatom ${ }^{41} \mathrm{czy}_{\text {wizytatorom }}{ }^{42}$. Pewną prawidłowością pozostaje jednak, iż wskazane użycie czasownika praescribere ma charakter negatywny, to znaczy zakazuje ono nabycia uprawnień i ujmuje ono problem przedawnienia (czy w zasadzie zakazuje przedawnienia) z perspektywy podmiotu, który bezprawnie usiłuje je nabyć.

Pozostawiając na marginesie powyższe trudności interpretacyjne, wydaje się, iż zasadniczy wniosek jaki płynie z powyższej analizy dotyczy faktu, że dopiero na okres pontyfikatu Innocentego III datować można dwojaki sposób rozumienia terminu praescriptio. Fakt ten jest o tyle ważny, iż podwójne rozumienie omawianego terminu zachowało się w nauce prawa kanonicznego do dziś. To właśnie w prawodawstwie Innocentego III należy poszukiwać uzasadnienia

\footnotetext{
${ }^{37}$ X. 2.26.2. Cytat z summarium autorstwa Johannesa Andrae poprzedzający dekretał.

${ }^{38}$ X. 2.26.3.

${ }^{39}$ X. $2.26 .4 ; 2.26 .15$

${ }^{40}$ X. 2.26.11.

${ }^{41}$ X. 2.26.12.

${ }^{42}$ X. 2.26.16.
} 
szerokiego rozumienia terminu praescriptio w prawie kanonicznym, jako wszelkiego wynikającego z upływu czasu, zgodnego z prawem, nabycia bądź utraty określonych rzeczy czy uprawnień. Jak zauważa bowiem P. Skonieczny OP - badając współczesne regulacje dotyczące tej materii - na kanoniczy termin praescriptio składają się używane $\mathrm{w}$ kanonistyce terminy praescriptio acquisitiva (usucapio) i praescriptio extinctiva seu liberativa ${ }^{43}$. Także sam prawodawca w kodyfikacji prawa kanonicznego wyraźnie wskazuje na dwoistość pojęcia praescriptio mówiąc, iż dotyczy ono tamquam modum iuris subiectivi acquirendi vel amittendi necnon ab obligationibus esse liberandi ${ }^{44}$.

Wracając do problemu dobrej wiary, należy zauważyć, iż zawarcie w kanonie Quoniam omne przekonania, iż bona fides niezbędna jest zawsze, a nie tylko w chwili wejścia na drogę do zasiedzenia rzeczy, czy rozpoczęcia biegu terminu do przedawnienia roszczenia czy innego uprawnienia, była jedynie częściowym novum. W kanonie soborowym wyrażono bowiem pogląd, którego ślady odnaleźć można już w początkach prawodawstwa kościelnego, a które wzmocnione zostało w latach poprzedzających zwołanie Soboru poprzez działalność prawodawczą Innocentego III.

Warto zauważyć jednak, iż formułując treść kanonu Ojcowie soborowi zaznaczyli, że ustanowione przez nich prawo ma obowiązywać $\mathrm{w}$ odniesieniu do praescriptio tam canonica quam civilis. Wprawdzie nakaz sprawowania posiadania w dobrej wierze rzeczywiście znany był już w epoce starożytnej, to jednak należy zwrócić uwagę, iż dotyczył on dotychczas jedynie dóbr kościelnych czy też - jak w IX stuleciu stwierdził papież Eugeniusz II - venerabilibus locis. W roku 1215 natomiast doszło do rozszerzenia zasady także na zasiedzenie,

\footnotetext{
${ }^{43} \mathrm{Na}$ temat współczesnej doktryny przedawnienia w prawie kanonicznym (KPK/83, kan. 197) i jej relacji do systemu prawa polskiego zob. P. SKoniecznY, Koncepcja przedawnienia kanonicznego. Uwagi prawnoporównawcze i teoretycznoprawne do kan. 197 KPK (kan. 1540 KKKW), ze szczególnym uwzględnieniem kanonizowanej ustawy polskiej, Prawo Kanoniczne 56(2013), nr 1, s. 3-30.

${ }^{44} \mathrm{~W}$ polskiej literaturze zob. obok powoływanej pracy P. Skoniecznego również R. Sobański, Komentarz do Kodeksu Prawa Kanonicznego, t. 1, Normy ogólne, Poznań 2003, s. 286-291.
} 
które regulowane było prawem świeckim. W tym też należy, jak się wydaje, upatrywać doniosłości kanonu Quoniam omne. Inną sprawą jest faktyczne oddziaływanie kościelnej regulacji na świeckie porządki prawne i recypowanie przez nie soborowej normy. Jak stwierdził bowiem H.J. Berman: „this provision of canon law conflicted sharply with the secular law in most part of Europe ${ }^{45 "}$.

Ostatecznie norma, która tak stanowczo wyrażona została w trakcie prac IV Soboru laterańskiego, potwierdzona została jako powszechnie obowiązująca reguła w roku 1298 w De Regulis iuris Bonifacego VIII w brzmieniu: Possessor malae fidei ullo tempore non praescribit $^{46}$.

\section{Zakończenie}

Wymóg dobrej wiary w kontekście zasiedzenia rzeczy, ilustrowany paremią mala fides superveniens nocet, stanowi jedną $\mathrm{z}$ fundamentalnych zasad systemowych prawa kanonicznego. Występuje on we współczesnym Kodeksie prawa kanonicznego z 1983 roku, jak również obowiązywał we wcześniejszym ustawodawstwie kościelnym. Większość autorów łączy genezę tej zasady z kanonem Quoniam omne, stanowiącym element prawodawstwa IV Soboru laterańskiego z 1215 roku. Co do zasady wymóg dobrej wiary rozumiany jest $\mathrm{w}$ doktrynie jako absentia peccat ${ }^{47}$. Błędne wydaje się jednak wskazywanie na Quoniam omne jako źródło obowiązywania powyższej zasady w prawie kanonicznym. Choć w czasach poprzedzających Sobór, $\mathrm{w}$ doktrynie dyskutowano na temat zasady dobrej wiary, a papieże

\footnotetext{
${ }^{45}$ H.J. Berman, Law and Revolution. The Formation of Western Legal Tradition, Cambridge, Mass. - London 1983, s. 245.

${ }^{46}$ VI. 5.12.2. Por. również dwa dekretały Bonifacego VIII włączone do tytułu De praescriptionibus Liber Sextus (VI. 2.13.1-2). Na temat późniejszych losów kategorii dobrej wiary zob. A. Földi, Traces of the Dualist Interpretation of Good Faith in the Ius Commune until the End of the Sixteenth Century, in Meditationes de iure et historia. Essays in honour of Laurens Winkel, red. R. van den Bergh, G. van Niekerk, P. Pichonnaz, P. Thomas, D. Kleyn, F. Lucrezi, J. Mutton, Pretoria 2014, s. 312-321.

${ }^{47}$ Zob. jednak A. Albisetri, Tra diritto ecclesiastico e canonico, Milano 2009, s. 123-125.
} 
wydawali dekretały dotyczące wymogu jej trwania przez cały czas trwania zasiedzenia, to jednak przekonanie o wadliwości dopuszczenia zasady mala fides superveniens non nocet dostrzec można już w prawodawstwie Kościoła starożytnego. Wraz z upływem wieków precyzował on jednak swoje zapatrywanie na ten temat, przechodząc od rozwiązań kazuistycznych, poprzez normy o charakterze generalnym (Vigilanti i Quoniam omne), a kończąc na regule prawa wpisanej do ich katalogu przez Bonifacego VIII.

\section{Bona fide praescriptio. Canon 41 Quoniam omne of the Fourth Lateran Council (1215) and Roman Law}

According to the common opinion the canonical rule that requires good faith throughout the whole period of the prescription was introduced in can. 41 Quoniam omne of the Fourth Lateran Council in 1215. It is believed also that the rule is a denial of Roman legal maxim mala fides superveniens non nocet. It this article an author is presenting the history of the fides requirement in Roman law as well as in the canon law until the times of Quoniam omne. The analysis proves that the opinion that the bona fides rule appeared suddenly in early $13^{\text {th }}$ century is false. The promulgation of the can. 41 was preceded by the long lasting tradition of the Church which implied the need of a good faith. The origins of such legal solution can be traced already in the proceedings of the ancient councils.

SŁowa Kluczowe: Prawo rzymskie; prawo kanoniczne; zasiedzenie; dobra wiara; IV Sobór laterański

Key wORDs: Roman law; Canon law; prescription; good faith; Fourth Lateran Council

\section{Nota o Autorze:}

Dr LUKASz JAN Korporowicz - adiunkt w Katedrze Prawa Rzymskiego Wydziału Prawa i Administracji Uniwersytetu Łodzkiego. Prawnik (UŁ, 2010) i kanonista (UKSW, 2016). Doktor nauk prawnych (rozprawa doktorska: Prawo rzymskie w orzecznictwie Izby Lordów w latach 1876-2009, wydana w formie książkowej przez Wydawnictwo UŁ, Łódź 2016, ss. 336). Autor około czterdziestu publikacji o charakterze naukowym. W swoich badaniach 
naukowych skupia się przede wszystkim na zagadnieniach: (1) wpływ prawa rzymskiego na angielski system prawny, (2) historia prawa angielskiego, (3) wpływ prawa rzymskiego na rozwój średniowiecznego prawa kanonicznego. 